\title{
Column studies on the removal of dissolved organic carbon, turbidity and heavy metals from stormwater using granular activated carbon
}

Danious P. Sounthararajah, Paripurnanda Loganathan, Jaya Kandasamy, and Saravanamuthu Vigneswaran ${ }^{*}$

Faculty of Engineering and Information Technology, University of Technology, Sydney, P.O. Box 123, Broadway, NSW 2007, Australia.

*corresponding author (Tel.: 612-95142641, Fax: 612-95142633, email:

s.vigneswaran@uts.edu.au

\begin{abstract}
Stormwater pollutants have the capacity to damage aquatic environments if they are discharged untreated. Suspended solids (turbidity) dissolved organic carbon (DOC) and heavy metals removals from stormwater were investigated in batch and fixed-bed column experiments. Field studies revealed that turbidity and DOC in stormwater were effectively removed at filtration velocities of 5,10 and $11.5 \mathrm{~m} / \mathrm{h}$ using a $100 \mathrm{~cm}$ height granular activated carbon (GAC) filter column. At the higher filtration velocities of 10 and $11.5 \mathrm{~m} / \mathrm{h}$, adding a pre-treatment $100 \mathrm{~cm}$ height anthracite filter column further improved DOC and turbidity removal. Batch and column laboratory adsorption experiments at $\mathrm{pH}$ 6.5-7.2 using GAC showed that the order of removal efficiency for solutions containing single and mixed metals was $\mathrm{Pb}, \mathrm{Cu}>\mathrm{Zn}>\mathrm{Ni}, \mathrm{Cd}$. This order was related to the solubility product and first hydrolysis constants of these metals' hydroxides. This study confirmed that GAC filter is effective in removing turbidity, DOC and heavy metals from stormwater.
\end{abstract}


Keywords: adsorption, dissolved organic carbon, granular activated carbon, heavy metals, turbidity

\section{Introduction}

Urban stormwater is the main source of pollution in water bodies such as lakes and rivers $[1,2]$. The stormwater carries a large number of organic and inorganic pollutants in colloidal and dissolved forms such as suspended solids (SS), dissolved organic carbon (DOC) and heavy metals [3]. These pollutants can have adverse effects on the environment when discharged in untreated form into receiving water bodies.

Suspended solids contribute to the water's turbidity, cause temperature changes and lessen sunlight penetration, which can reduce the resulting activity and growth of photosynthetic organisms. This leads to aesthetic issues, higher cost of water treatment, declining fish resources, serious ecological degradation of aquatic life, reduced navigability of channels and decreased longevity of dams and reservoirs $[3,4]$. Suspended solids also work as carriers of pollution because the finer sediments carry pollutants such as heavy metals, pesticides, nutrients and organic matter in particulate form and release them into the environment [4].

Dissolved organic carbon causes oxygen deficiency in water and subsequently leads to the death of aquatic organisms [5,6]. It also creates an unpleasant taste and odour in water and acts as a substrate to microbial growth. Furthermore, DOC can reduce the effectiveness of water treatment processes $[7,8]$, increase coagulant and disinfection demands, and foul membrane filters $[9,10]$.

Several studies have found significant levels of heavy metal contaminants such as $\mathrm{Ni}$, $\mathrm{Cu}, \mathrm{Cd}, \mathrm{Zn}$, and $\mathrm{Pb}$, in urban stormwater which can heavily pollute receiving water bodies $[1,3,11]$. Heavy metals such as $\mathrm{Pb}, \mathrm{Hg}$ and $\mathrm{Cd}$ are in the top seven hazardous chemicals listed 
by the US Agency for Toxic Substances and Disease Registry [12]. Many studies have reported on the adsorptive removal of organic and inorganic contaminants from stormwater. These are, however, limited to mostly static batch studies instead of the dynamic fixed-bed column studies which are more relevant to actual operating systems in treatment plants $[13,14]$.

The purpose of this study was to investigate the efficiency in removing a wide range of pollutants from urban stormwater using granular activated carbon (GAC) and anthracite by fixed-bed field and laboratory column filtration, thereby preventing the contaminant loading to waterways and increasing the likelihood of recycle and reuse of stormwater. The specific contaminants studied in this paper are DOC, SS and heavy metals $(\mathrm{Cu}, \mathrm{Zn}, \mathrm{Pb}, \mathrm{Cd}$ and $\mathrm{Ni})$. Other contaminants, such as polycyclic aromatic hydrocarbons (PAHs) in stormwater, were not studied as their concentrations were very low (concentrations of water sediments from where the PAHs leach to stormwater were 0.49-5.29 $\mu \mathrm{g} / \mathrm{g}[15])$. In field experiments, natural stormwater served in the analysis of removing DOC and SS using anthracite and GAC columns in series with different filtration velocities. The removal of heavy metals was not studied in the field because their concentrations in natural stormwater are extremely small. In laboratory studies, tap water was spiked with heavy metals and kaolinite to test the ability of heavy metals, turbidity and DOC removals using GAC.

\section{Experimental methodology}

\subsection{GAC and anthracite}

Granular activated carbon and anthracite used in the study were obtained from James Cummins P/L, Australia. Selected properties of the GAC and anthracite are summarised in Table 1. Zeta potential which is related to the surface charge of the adsorbent was measured in GAC suspensions using a zetasizer nano-instrument (Nano ZS Zne 3600, Malvern, UK). 
For each sample the instrument automatically created replicate measurements and a mean value was produced. Zeta potential was measured at $\mathrm{pH} 3$ to 10 , after adjusting the $\mathrm{pH}$ of a $100 \mathrm{ml}$ suspension of adsorbent in deionised water $(0.1 \mathrm{~g} / \mathrm{L})$ and agitating it at $120 \mathrm{rpm}$ for 6 hours.

\section{TABLE 1}

\subsection{Stormwater}

The stormwater used in field studies was predominantly from the base flow in a stormwater harvesting plant located at Lower West Street Reserve, Carlton in Sydney (S 33.979972, E 151.115360), which constantly flowed in the stormwater canal between rainfall

events. Rainfall on $1^{\text {st }}, 2^{\text {nd }}$ and $3^{\text {rd }}$ day of the field experiment was $19,13,84 \mathrm{~mm}$ measured at a weather station close to the site. The stormwater was drained by gravity through a sump pit in the floor of the stormwater canal to an adjacent wet well. It was then pumped through a control valve pit to a collection tap, from which point the stormwater was continuously fed directly to the fixed-bed absorbent columns at a velocity controlled by valves before and after the filter columns. Table 2 presents the stormwater characteristics. For laboratory experiments, synthetic stormwater was prepared using tap water to produce a mix of heavy metals and kaolinite which had the specified required concentrations of metals and turbidity.

\section{TABLE 2}

\subsection{Kaolinite and chemicals}

Kaolinite (aluminium silicate CAS no. 1302-93-8) used in the study was obtained from Sigma Aldrich (USA). Analar grade nitrate salts of heavy metals $(\mathrm{Cu}, \mathrm{Zn}, \mathrm{Pb}, \mathrm{Cd}$, and $\mathrm{Ni}$, CAS No's 10031-43-3, 10196-18-6, 10099-74-8, 10022-68-1 and 13478-00-7, respectively) 
were utilised in the study.

\subsection{Field fixed-bed column experiments}

A schematic diagram of the different media filters set-up in the field is shown in Fig. 1(a). The media used in the experiments conducted in dynamic adsorption conditions were anthracite and GAC. Field experiments were conducted using $10 \mathrm{~cm}$ internal diameter PVC columns, one packed with anthracite and two with GAC to a height of $100 \mathrm{~cm}$. As shown in Fig. 1(a), two filtration set-ups were used: i) an anthracite filter column followed by a GAC column; and ii) a single GAC filter column. The anthracite filter column was used before the GAC filter to test the necessity of pre-treatment at different hydraulic loadings. High SS loading to the GAC filter may hinder its ability to effectively remove other pollutants such as organics from stormwater by clogging its active pores. Anthracite was chosen as a pretreatment filter material due to cost considerations and its ability to effectively remove suspended solids [16-18]. The flow rates of stormwater through the columns were $5 \mathrm{~m} / \mathrm{h}, 10$ $\mathrm{m} / \mathrm{h}$ and $11.5 \mathrm{~m} / \mathrm{h}$, for 1-2 d, 3-4 d, and 5-6 d, respectively. At these flow rates the empty bed contact times (EBCT) were 12, 6, and $5.2 \mathrm{~min}$, respectively. At the end of each day of operation of 4-6 h filtration, the columns were backwashed with tap water for 1 min and kept in a moist state overnight $(18 \mathrm{~h})$ until the filtration experiments re-commenced the following day.

Influent and effluent samples from each column were collected at 5, 10, 15, and $30 \mathrm{~min}$ intervals, and afterwards every hour. Turbidity in a portion of each sample was measured using a Hach Model 2100P Turbidimeter. Samples were then filtered through $0.45 \mu \mathrm{m}$ filter disks and DOC in the filtrate was measured using a Multi N/C 2000 analyzer (Analytik Jena AG). 


\subsection{Laboratory batch experiments}

Batch adsorption experiments were conducted under static condition in a closed system to obtain information on the adsorptive properties of each of the heavy metals on GAC. Anthracite was not tested because its properties tend to be inert toward heavy metals compared to GAC [16]. Initial metal concentration used in these experiments was $5 \mathrm{mg} / \mathrm{L}$. Doses of adsorbent ranging from 0.1 to $7.5 \mathrm{~g} / \mathrm{L}$ served to provide a range (low to high values) of equilibrium concentrations and adsorption capacities of metals. Initial $\mathrm{pH}$ was kept at $6.5 \pm$ 0.1 to simulate a $\mathrm{pH}$ close to that of natural stormwater (Table 2).

In the adsorption experiments, $100 \mathrm{ml}$ metal solutions were mixed with specified adsorbent dose and agitated at $120 \mathrm{rpm}$ in a flat shaker for $24 \mathrm{~h}$ at room temperature $\left(24 \pm 0.5^{\circ} \mathrm{C}\right)$. The solution ionic strength was kept at $10^{-3} \mathrm{M} \mathrm{NaNO}_{3}$. The suspensions were then filtered using filter disks with $0.45 \mu \mathrm{m}$ pore opening and heavy metal concentrations in the filtrate were analysed. Heavy metals were measured using an atomic absorption spectrophotometer (AAS) (ContraAA 300). The amount of heavy metal absorption at equilibrium, $\mathrm{q}_{\mathrm{e}}(\mathrm{mg} / \mathrm{g})$ was calculated by subtracting the amount of metals in the solution at equilibrium from the amount of metals added using the following formula:

$q_{e}=\frac{\left(C_{o}-C_{e}\right) V}{M}$

where, $\mathrm{C}_{0}=$ initial concentration of heavy metal $(\mathrm{mg} / \mathrm{L}) ; \mathrm{C}_{\mathrm{e}}=$ equilibrium concentration of the heavy metal $(\mathrm{mg} / \mathrm{L}) ; \mathrm{V}=$ volume of the solution $(\mathrm{L})$ and $\mathrm{M}=$ mass of GAC $(\mathrm{g})$. The efficiency in removing heavy metals was calculated using the following formula:

Removal Efficiency $(\%)=\frac{\left(C_{o}-C_{e}\right)}{C_{o}} * 100 \%$

The experiments were repeated for multi-metals adsorption in order to determine the 
effect of co-existing heavy metal ions on each metal being removed. The concentrations of $\mathrm{Zn}, \mathrm{Cd}, \mathrm{Ni}, \mathrm{Pb}$, and $\mathrm{Cu}$ were $10.0,0.2,0.3,5.0,3.0 \mathrm{mg} / \mathrm{L}$, respectively. The heavy metal concentrations used were approximately ten times the maximum concentrations reported for Australian stormwater [11]. Doses of adsorbent used varied from 0.5 to $10 \mathrm{~g} / \mathrm{L}$.

\subsection{Laboratory fixed-bed column experiments}

A schematic diagram of the GAC filtration unit set-up in the laboratory is shown in Fig. 1(b). Initially, the GAC was packed into a 2-cm internal diameter transparent acrylic fibre column to $90 \mathrm{~cm}$ height (100 $\mathrm{g}$ of GAC) and deionised water was passed upwards through the column for 5 min to expel air within the pores of the particles. Filtration experiments were then conducted using synthetic stormwater at a filtration velocity of $5 \mathrm{~m} / \mathrm{h}$ in the gravity flow mode using two peristaltic pumps; one before the water enters to the column and the other when the water leaves the column. The empty bed contact time (EBCT) at this filtration velocity was $10.8 \mathrm{~min}$.

\section{FIG. 1}

Heavy metal concentrations in the influent natural stormwater were extremely low (Table 2) compared to the average concentrations found in stormwater reported across Australia [11]. Therefore, in the experiments on removing heavy metals with GAC, tap water was spiked with heavy metals to produce the required concentrations of heavy metals. The concentrations of the heavy metals $\mathrm{Zn}, \mathrm{Cd}, \mathrm{Ni}, \mathrm{Pb}$ and $\mathrm{Cu}$ used in this study were 2.0, 0.04, $0.06,1.0,0.6 \mathrm{mg} / \mathrm{L}$, respectively. These concentrations were approximately twice the maximum concentrations reported for Australian stormwaters [11]. To simulate turbidity in the water, the tap water was also spiked with kaolinite at a concentration of $7 \mathrm{mg} / \mathrm{L}$. This 
produced a desired turbidity which is an average of the values for the stormwater at Carlton (Table 2). The tap water was not spiked with any organics since it already contained a DOC level of $5.1 \mathrm{mg} / \mathrm{L}$ which was close to the DOC levels found in the field (Table 2). Samples were collected at $10 \mathrm{~min}$ and $30 \mathrm{~min}$, thereafter every hour for $8 \mathrm{~h}$ and then less frequently for up to $120 \mathrm{~h}$. The effluent samples were analysed for DOC, heavy metals, $\mathrm{pH}$ and turbidity.

The cumulative column adsorption capacity, $\mathrm{q}$ total $(\mathrm{mg})$, for a given feed concentration and filtration velocity is equal to the area under the plot of the adsorbed metal concentration, $\mathrm{C}_{\mathrm{ad}}\left(\mathrm{C}_{\mathrm{ad}}=\mathrm{C}_{\mathrm{o}^{-}}-\mathrm{C}_{\mathrm{e}}\right)(\mathrm{mg} / \mathrm{L})$ with time $(\mathrm{t}$, min). It was calculated from the breakthrough curves according to equation (3) where $\mathrm{Q}$ is the flow rate of the solution (L/min):

$q_{\text {total }}=\frac{Q}{1000} \int_{t=0}^{t=120 h} C_{a d} d t$

\section{Results and discussion}

\subsection{Zeta potential of GAC}

Zeta potentials of GAC were $+18.0,+13.2,+7.8,-11.6,-16.9$, and $-28.9 \mathrm{mV}$ at the final suspension $\mathrm{pHs}$ of $3.12,3.57,4.80,6.24,6.64$, and 8.00 , respectively. Therefore the zero point of charge (ZPC, pH at which zeta potential is zero) of GAC tested was 4.8-6.2. This agrees with the ZPC values of 5.4 and 5.5 reported by Sepúlveda et al. [19] and Wei et al. [20] for GAC, respectively. At $\mathrm{pH}$ less than the ZPC, GAC carries a net positive surface charge and at $\mathrm{pH}$ above the $\mathrm{ZPC}$, it carries predominantly negative charges. Therefore, in our experiments, GAC had more negative charges at the $\mathrm{pH}$ of 6.5 which indicates that GAC had a high affinity for adsorbing heavy metals that are present as cations.

\subsection{Field fixed-bed column experiments}




\subsubsection{DOC and turbidity removal}

Field experiments were conducted in order to test the removal efficiency of DOC and turbidity by GAC filter column operated at different filtration velocities and the possibility of improving the turbidity removal by using a pre-treatment of anthracite filtration before GAC filtration. Fig. 3 presents the temporal variation of turbidity and DOC removal by GAC filter column operating intermittently in the field over a period of six days. The turbidity and DOC levels of the influent raw stormwater during the experiment varied in the range of 3-343 NTU and 4.3-16.6 $\mathrm{mg} / \mathrm{L}$, respectively. The large variation in turbidity and DOC levels is due to the storm events that had occurred in the days prior to the experiment. Regardless of the huge variation in the influent turbidity and DOC of the stormwater, GAC filter and anthracite filter + GAC filter performed well in removing up to $98.5 \%$ of turbidity for both filter arrangements and up to $96.0 \%$ and $97.5 \%$ of turbidity, respectively during the six days of intermittent operation. On average, the single GAC filter and the anthracite filter followed by GAC filter removed $71 \%$ and $78 \%$ of DOC, respectively, and $65.5 \%$ and $75 \%$ of turbidity, respectively.

The anthracite filter removed a small fraction of DOC (7\%) but $67 \%$ of turbidity when it operated in a series as a pre-treatment strategy before GAC. The DOC and turbidity of the effluent from the GAC filter were 0.2-3.9 $\mathrm{mg} / \mathrm{L}$, and 1.9-13.0 NTU, respectively. The corresponding values for the effluent from the anthracite filter followed by GAC filter were 0.3-3.5 mg/L and, 1.0-8.0 NTU, respectively. This demonstrates that a single GAC filter and anthracite followed by GAC filter effectively removed turbidity and DOC. Adding a pretreatment of an anthracite filter significantly reduced turbidity and the suspended solids loading to the subsequent GAC column. A negligible improvement was observed in the removal of DOC by anthracite pre-treatment because of the inert adsorption properties of anthracite compared to GAC. Kus et al. [2] also discovered that on average, an anthracite 
column with the same column height of $100 \mathrm{~cm}$ and filtration rate of $10 \mathrm{~m} / \mathrm{h}$ could remove only $11 \%$ of total organic carbon (TOC) from an influent TOC concentration of 3.9-9.7 mg/L during 3 days of filtration. However, for an influent turbidity of 14.5-48.5 NTU, the average effluent turbidity was 8 NTU. The pre-treatment with anthracite could provide a screening barrier to the GAC filter column, so clogging of GAC can be reduced to improve the performance of the GAC filter.

\section{FIG. 2}

\section{TABLE 3}

The mechanism used to remove DOC was mainly adsorption onto surface functional groups of GAC by hydrogen bonding and van der Waals forces [21]. Xing et al. [22] reported that the removal of DOC by GAC in the early stages was governed by adsorption but once the GAC was saturated with adsorption, after a week, microbes started to develop on the GAC and it functioned as a biofilter. Growth of microbes within 6 days of intermittent usage in the current study is unlikely and therefore the removal of DOC is ascribed mainly to adsorption. GAC's removal of turbidity occurred predominantly through physical retention.

\section{TABLE 4}

Table 4 shows the effect of filtration velocity on the removal of DOC and turbidity using GAC and anthracite + GAC filter columns. At a filtration velocity of $5 \mathrm{~m} / \mathrm{h}$, both filtration systems showed higher removal efficiency of DOC and turbidity compared to the 10 and $11.5 \mathrm{~m} / \mathrm{h}$ filtration velocities. Increases in the filtration velocity reduced the efficiency of the single GAC column system more than that of anthracite and GAC filters in series for the removal of both DOC and turbidity. The anthracite + GAC filter system always performed better in removing DOC and turbidity at all velocities studied. These results indicate that high removal efficiencies can be achieved by single GAC without pre-treatment for lower velocities but at higher velocities pre-treatment is necessary to achieve high efficiency in 
removing DOC and turbidity.

\subsection{Laboratory batch experiments}

\subsubsection{Heavy metal adsorption by GAC}

\subsubsection{Individual metals}

Fig. 3 illustrates the removal efficiencies of all metals studied which followed the order of $\mathrm{Pb}, \mathrm{Cu}>\mathrm{Zn}>\mathrm{Ni}, \mathrm{Cd}$ at $\mathrm{pH} 6.5$. This is the same order as the solubility product constant of metal hydroxide $\left(\mathrm{M}(\mathrm{OH})_{2}\right)$ precipitate $\left(\mathrm{pK}_{\mathrm{s}}\right.$ of metal hydroxides for $\mathrm{Pb}, \mathrm{Cu}, \mathrm{Zn}, \mathrm{Ni}$, and $\mathrm{Cd}$ are $19.9,19.3,16.5,15.2$, and 14.4 , respectively $[23,24])$. It is also in the reverse order as the first hydrolysis constant of the metals $\left(\mathrm{MOH}^{+}\right.$formation) $\left(\mathrm{pk}_{1}\right.$ of metal hydroxyl complexes for $\mathrm{Pb}, \mathrm{Cu}, \mathrm{Zn}, \mathrm{Ni}$, and $\mathrm{Cd}$ are 7.7, 7.9, 9.0, 9.9, and 10.1, respectively [25-27]). The higher the $\mathrm{pK}_{\mathrm{s}}$ value the greater the metal's tendency to precipitate as the metal hydroxide, while a lower $\mathrm{pk}_{1}$ value reveals that the metal produces a soluble metal hydroxyl complex more easily. The higher adsorption capacity of the metals with a high $\mathrm{pk}_{\mathrm{s}}$ values is due to these metals forming surface precipitation on the adsorbent [28]. Surface precipitation can occur at $\mathrm{pHs}$ lower than those at which precipitation occurs in solution because the adsorbent provides a nucleus to induce precipitation. Metal hydroxyl complexes have higher affinity for adsorption than divalent metal ions. Therefore metals which readily form hydroxyl complexes (lower $\mathrm{pk}_{1}$ values, e.g. $\mathrm{Cu}$ and $\mathrm{Pb}$ ) had higher adsorption capacities.

\section{FIG. 3}

\subsubsection{2. $\quad$ Mixed metals}

Fig. 4 shows the removal efficiencies of mixed metals at various concentrations. The heavy metals used in this study were $\mathrm{Zn}, \mathrm{Cd}, \mathrm{Ni}, \mathrm{Pb}$ and $\mathrm{Cu}$ and their concentrations were $10.0,0.2,0.3,5.0,3.0 \mathrm{mg} / \mathrm{L}$, respectively. This initial concentration of metals followed an 
order of $\mathrm{Zn}>\mathrm{Pb}>\mathrm{Cu}>\mathrm{Ni}>\mathrm{Cd}$ but the removal efficiencies of metals followed the order of $\mathrm{Pb}, \mathrm{Cu}>\mathrm{Zn}>\mathrm{Ni}, \mathrm{Cd}$. The latter order is similar to single metal adsorption despite the huge differences in the initial concentrations. This may be because the adsorption of metals is more governed by mechanisms of adsorption discussed earlier than the initial concentrations in the mixture that were used [26].

\section{FIG. 4}

\subsection{Laboratory fixed-bed column experiments}

\subsubsection{Heavy metal removal}

Column breakthrough curves for all metals tested are presented in Fig. 5. The breakthrough for $\mathrm{Cu}$ was achieved after $24 \mathrm{~h}(133 \mathrm{BV})$ but the exhaustion point did not occur until $120 \mathrm{~h}(666 \mathrm{BV})$. For $\mathrm{Pb}$, no clear breakthrough occurred in the $120 \mathrm{~h}$ of filter operation. However, for $\mathrm{Cd}, \mathrm{Zn}$ and $\mathrm{Ni}$ a breakthrough commenced as early as $8 \mathrm{~h}$ and exhaustion was nearly completed for $\mathrm{Ni}, \mathrm{Cd}$ within $24 \mathrm{~h}$ of operation. Zn breakthrough was nearly completed after $120 \mathrm{~h}$. These results agree with those of others reported in literature for other adsorbents. For example, Apiratikul and Pavasant [29] reported that the breakthrough time of metals at $\mathrm{pH} 5$ in dried green algae fixed-bed columns was longest for $\mathrm{Pb}$ followed by $\mathrm{Cu}$ and Cd. They also stated that the average adsorption capacity calculated from the breakthrough curves followed the order of $\mathrm{Pb}>\mathrm{Cu}>\mathrm{Cd}$. Similarly, Jeon et al. [30] reported that the time taken for the effluent concentration of metals to reach the influent concentrations $(\mathrm{Ce} / \mathrm{Co}=1)$ was longer for $\mathrm{Cu}$ than $\mathrm{Cd}$ when the metal solutions at $\mathrm{pH} 3$ were passed through zeolite and iron oxide coated zeolite columns. During the entire experiment, no $\mathrm{Pb}$ was detected in the effluent of any of the columns.

The steepness of the breakthrough curves followed an order of $\mathrm{Pb}, \mathrm{Cu}>\mathrm{Zn}>\mathrm{Ni}, \mathrm{Cd}$ in 
GAC columns which is similar to that of single metal and mixed metals batch adsorption results. The cumulative removal of heavy metals and the cumulative percentage of metals removed after $120 \mathrm{~h}(666 \mathrm{BV})$ of operation also followed the same order. Pagnanelli et al. [26] cited many references in the literature for the adsorption of heavy metals on several inorganic and organic adsorbents in both batch and column studies where the order of adsorption was similar to the currect study. In addition to the reasons given for this trend earlier, when discussing the batch studies, such as solubility products of metal hydroxide precipitate and hydrolysis constants of the metals, the differences in concentration of metals in the influent solution can also explain the adsorption differences between metals. $\mathrm{Cd}$ and $\mathrm{Ni}$ adsorption was low compared to the other metals considered in the column study because: firstly, these metals had relatively low concentrations of these metals in the influent water; and secondly, the low adsorption capacities of these metals on GAC as found in single metal batch adsorption results.

\section{FIG. 5}

\section{TABLE 5}

\subsubsection{Turbidity and DOC removal}

Fig. 6 shows the influent and effluent values of DOC and turbidity of laboratory GAC column using synthetic stormwater. Influent DOC and turbidity levels were $5.1 \mathrm{mg} / \mathrm{L}$ and 15.4 NTU, respectively, and the corresponding effluent values were $0-0.3 \mathrm{mg} / \mathrm{L} \mathrm{DOC}$ and 1.6-4.5 NTU turbidity for $120 \mathrm{~h}$ of continuous operation. On average, GAC removed $98 \%$ of DOC and $80 \%$ of turbidity from the stormwater at a filtration velocity of $5 \mathrm{~m} / \mathrm{h}$ which is comparable to the results obtained in the field. In the field $83 \%$ of DOC and $84 \%$ of turbidity were removed by GAC columns of approximately the same height at the same filtration velocity. The mechanism for removing turbidity involves physical screening, whereas that for 
DOC removal is mainly through chemical adsorption which is governed by H-bonding and Van der Waals forces [21].

\section{FIG. 6}

\subsection{Feasibility study and optimum conditions}

The batch and column studies showed that pollutants from urban stormwater such as DOC, turbidity and heavy metals can be effectively removed by single $100 \mathrm{~cm}$ height GAC column at a filtration velocity of $5 \mathrm{~m} / \mathrm{h}$. At the higher filtration velocities of 10 and $11.5 \mathrm{~m} / \mathrm{h}$, DOC and turbidity removal efficiencies fell, but a pre-treatment column with anthracite before GAC treatment improved the performance of the GAC column system. Depending on the levels of pollutants at the specific site, suitable operational conditions may change. Therefore, a series of experiments similar to the current study need to be conducted at different concentrations of pollutants, filtration velocities and column height to determine the optimum conditions for various scenarios. There is no single optimum condition for the operation because it will vary depending on the water pollutants and column characteristics.

The results obtained on heavy metals removal using synthetic wastewater (tap water spiked with heavy metals) may not be directly applicable to real stormwater. Therefore the results need to be confirmed on real stormwater having high concentrations of heavy metals.

\section{Conclusions}

A GAC fixed-bed filter column and a series of anthracite filter followed by GAC filter effectively removed DOC and turbidity from stormwater. A single GAC filter column operating at a lower filtration velocity of $5 \mathrm{~m} / \mathrm{h}$ was able to remove most of the DOC and turbidity. At higher filtration velocities of $10 \mathrm{~m} / \mathrm{h}$ and $11.5 \mathrm{~m} / \mathrm{h}$, an additional pre-treatment of anthracite filter to the GAC filter enhanced the overall effectiveness. At natural pHs of 
stormwater (6.9-7.2), the GAC filter column showed high absorptive removal for $\mathrm{Pb}$, and $\mathrm{Cu}$. GAC adsorption of $\mathrm{Zn}, \mathrm{Cd}$ and $\mathrm{Ni}$ over $120 \mathrm{~h}$ of continuous operation at a filtration velocity of $5 \mathrm{~m} / \mathrm{h}$ was moderate. Batch adsorption of single and mixed metals had the same removal order as in column studies. The removal of metals followed the order of $\mathrm{Pb}, \mathrm{Cu}>\mathrm{Zn}>\mathrm{Ni}$, Cd which can be explained by the solubility product and first hydrolysis constants of these metal hydroxides.

\section{Acknowledgement}

This study was funded by Cooperative Research Centre for Contamination Assessment and Remediation of the Environment (CRC CARE) (project number 02-050-07).

\section{References}

[1] H. Lee, X. Swamikannu, D. Radulescu, S.-J. Kim, M.K. Stenstrom, Design of stormwater monitoring programs, Water Res., 41 (2007) 4186-4196.

[2] B. Kus, J. Kandasamy, S. Vigneswaran, H. Shon, G. Moody, Two stage filtration for stormwater treatment: A pilot scale study, Desalin. Water. Treat., 45 (2012) 361-369.

[3] R. Aryal, S. Vigneswaran, J. Kandasamy, R. Naidu, Urban stormwater quality and treatment, Korean J. Chem. Eng., 27 (2010) 1343-1359.

[4] G.S. Bilottaa, R.E. Brazier, Understanding the influence of suspended solids on water quality and aquatic biota, Water Res., 42 (2008) 2849 -2861.

[5] Victoria Stormwater Committee, Urban Stormwater: Best Practice Environmental Management Guidelines, CSIRO Publishing, Melbourne, 1999. 
[6] P.A. Ryan, Environmental effects of sediment on New Zealand streams: A review, New Zeal. J. Mar. Fresh., 25 (1991) 207-221.

[7] CRC, Natural Organic Matter, Understanding and Controlling the Impact on Water Quality and Water Treatment Processes, Water Quality and Teatment, South Australia, 2005.

[8] A. Matilainen, M. Vepsäläinen, M. Sillanpää, Natural organic matter removal by coagulation during drinking water treatment: A review, Adv. Colloid Interface Sci., 159 (2010) 189-197.

[9] R. Fabris, C.W.K. Chow, M. Drikas, B. Eikebrokk, Comparison of NOM character in selected Australian and Norwegian drinking waters, Water Res., 42 (2008) 4188-4196.

[10]A.W. Zularisam, A.F. Ismail, R. Salim, Behaviours of natural organic matter in membrane filtration for surface water treatment: A review, Desalination, 194 (2006) 211231.

[11] T.H.F. Wong, P.F. Breen, S.D. Lloyd, Water Sensitive Road Design: Design Options for Improving Stormwater Quality of Road Runoff, CRC for Catchment Hydrology, 2000.

[12] US Agency for Toxic Substances and Disease Registry, Priority List of Hazardous Substances, Sorted by Rank, Division of Toxicology and Environmemtal Medicine, Atlanda, GA, 2014.

[13] J.P. Chen, Decontamination of Heavy Metals: Processes, Mechanisms, and Applications, CRC Press, Florida, 2012. 
[14] J.P. Chen, J.T. Yoon, S. Yiacoumi, Effects of chemical and physical properties of influent on copper sorption onto activated carbon fixed-bed columns, Carbon, 41 (2003) $1635-1644$.

[15] T.C. Nguyen, P. Loganathan, T.V. Nguyen, S. Vigneswaran, J. Kandasamy, D. Slee, G. Stevenson, R. Naidu, Polycyclic aromatic hydrocarbons in road-deposited sediments, water sediments, and soils in Sydney, Australia: Comparisons of concentration distribution, sources and potential toxicity, Ecotox. Environ. Safe., 104 (2014) 339-348.

[16] T. Mohammed, S. Vigneswaran, J. Kandasamy, Bio-filtration as pre-treatment to water harvesting and recycling, Water Sci. Technol., 63 (2011) 2097-2105.

[17] M.A.H. Johir, S. Vigneswaran, J. Kandasamy, Deep bed filter as pre-treatment to stormwater, Desalin. Water. Treat., 12 (2009) 313-323.

[18] M.R. Templeton, R.C. Andrews, R. Hofmann, Removal of particle-associated bacteriophages by dual-media filtration at different filter cycle stages and impacts on subsequent UV disinfection, Water Res., 41 (2007) 2393-2406.

[19] C. Sepúlveda, R. García, P. Reyes, I.T. Ghampson, J.L.G. Fierro, D. Laurenti, M. Vrinat, N. Escalona, Hydrodeoxygenation of guaiacol over $\mathrm{ReS}_{2} /$ activated carbon catalysts. Support and Re loading effect, Appl. Catal. A-Gen., 475 (2014) 427-437.

[20] M.C. Wei, K.S. Wang, I.C. Lin, T.E. Hsiao, Y.N. Lin, C.T. Tang, J.C. Chen, S.H. Chang, Rapid regeneration of sulfanilic acid-sorbed activated carbon by microwave with persulfate, Chem. Eng. J., 193-194 (2012) 366-371.

[21] P. Loganathan, S. Vigneswaran, J. Kandasamy, R. Naidu, Defluoridation of drinking water using adsorption processes, J. Hazard. Mater., 248-249 (2013) 1-19. 
[22] W. Xing, H.H. Ngo, S.H. Kim, W.S. Guo, P. Hagare, Adsorption and bioadsorption of granular activated carbon (GAC) for dissolved organic carbon (DOC) removal in wastewater, Bioresour. Technol., 99 (2008) 8674-8678.

[23] S.R. Rao, Resource Recovery and Recycling from Metallurgical Wastes, Elsevier, Amsterdam, 2011.

[24] J.D. Walker, M.C. Newman, M. Enache, Fundamental QSARs for Metal Ions, CRC Press, Florida, 2012.

[25] M. Malandrino, O. Abollino, A. Giacomino, M. Aceto, E. Mentasti, Adsorption of heavy metals on vermiculite: Influence of pH and organic ligands, J. Colloid Interface Sci., 299 (2006) 537-546.

[26] F. Pagnanelli, A. Esposito, L. Toro, F. Vegliò, Metal speciation and pH effect on $\mathrm{Pb}, \mathrm{Cu}$, $\mathrm{Zn}$ and Cd biosorption onto Sphaerotilus natans: Langmuir-type empirical model, Water Res., 37 (2003) 627-633.

[27] A. Pohlmeier, In: M. N. V. Prasad, Heavy Metal Stress in Plants: From Biomolecules to Ecosystems, Springer, Berlin 2004, pp. 28-46.

[28] P. Loganathan, S. Vigneswaran, J. Kandasamy, N.S. Bolan, Removal and recovery of phosphate from water using sorption, Crit. Rev. Environ. Sci. Technol., 44 (2014) 847907.

[29] R. Apiratikul, P. Pavasant, Batch and column studies of biosorption of heavy metals by Caulerpa lentillifera, Bioresour. Technol., 99 (2008) 2766-2777.

[30] C.S. Jeon, S.W. Park, K. Baek, J.S. Yang, J.G. Park, Application of iron-coated zeolites (ICZ) for mine drainage treatment, Korean J. Chem. Eng., 29 (2012) 1171-1177. 
Table 1. Physical properties of GAC and anthracite

\begin{tabular}{lccc}
\hline \multicolumn{1}{c}{ Properties } & GAC & Anthracite & Reference \\
\hline Nominal size $(\mathrm{mm})$ & $0.3-2.38$ & $1.0-1.1$ & {$[16],[2]$} \\
Bulk density $\left(\mathrm{kg} / \mathrm{m}^{3}\right)$ & 748 & $660-720$ & {$[2]$} \\
Iodine number $(\mathrm{mg} / \mathrm{g} \cdot \mathrm{min})$ & 800 & - & {$[2]$} \\
BET surface area $\left(\mathrm{m}^{2} / \mathrm{g}\right)$ & 750 & - & {$[2]$} \\
Maximum Moisture content $(\%)$ & 5 & - & {$[2]$} \\
Uniformity coefficient & - & 1.30 & {$[16],[2]$} \\
Acid solubility $(\%)$ & - & 1 & {$[16],[2]$} \\
Specific gravity & - & 1.45 & {$[2]$} \\
\hline
\end{tabular}


Table 2. General characteristics of stormwater collected in Carlton, Sydney [16]

\begin{tabular}{|c|c|c|}
\hline Parameter & Unit & Value \\
\hline \multicolumn{3}{|c|}{ Physical and chemical properties } \\
\hline $\mathrm{pH}$ & - & $6.68-7.28$ \\
\hline TOC & $\mathrm{mg} / \mathrm{L}$ & $4.25-8.96$ \\
\hline Turbidity & NTU & $1.5-370$ \\
\hline True Colour & $\mathrm{PtCo}$ & $18-270$ \\
\hline Bicarbonate & $\mathrm{mg} / \mathrm{L} \mathrm{CaCO} 3$ equivalent & $30-95$ \\
\hline Water Hardness & $\mathrm{mg} / \mathrm{L} \mathrm{CaCO} 3$ equivalent & $22-145$ \\
\hline \multicolumn{3}{|l|}{ Metals } \\
\hline $\mathrm{Al}$ & $\mathrm{mg} / \mathrm{L}$ & $0.028-0.188$ \\
\hline As & $\mathrm{mg} / \mathrm{L}$ & $0.001-0.005$ \\
\hline $\mathrm{Cd}$ & $\mathrm{mg} / \mathrm{L}$ & $0.0009-0.001$ \\
\hline $\mathrm{Cr}$ & $\mathrm{mg} / \mathrm{L}$ & $0.002-0.002$ \\
\hline $\mathrm{Cu}$ & $\mathrm{mg} / \mathrm{L}$ & $0.008-0.049$ \\
\hline $\mathrm{Fe}$ & $\mathrm{mg} / \mathrm{L}$ & $0.05-2.55$ \\
\hline $\mathrm{Mn}$ & $\mathrm{mg} / \mathrm{L}$ & $0.001-0.024$ \\
\hline $\mathrm{Ni}$ & $\mathrm{mg} / \mathrm{L}$ & $0.003-0.10$ \\
\hline $\mathrm{Pb}$ & $\mathrm{mg} / \mathrm{L}$ & $0.001-0.022$ \\
\hline $\mathrm{Se}$ & $\mathrm{mg} / \mathrm{L}$ & $0.001-0.004$ \\
\hline
\end{tabular}


Table 3. DOC and turbidity levels in influent and effluent water (based on 9-11 samples taken daily for 6 consecutive days)

\begin{tabular}{ccccc}
\hline \multirow{2}{*}{ Treatment Chain } & \multicolumn{2}{c}{ DOC (mg/L) } & \multicolumn{2}{c}{ Turbidity (NTU) $^{1}$} \\
& Influent $^{1}$ & Effluent $^{1}$ & Influent $^{1}$ & Effluent $^{1}$ \\
\hline Single GAC filter & $6.4 \pm 0.3$ & $1.8 \pm 0.6$ & $26.1 \pm 4.8$ & $4.8 \pm 0.4$ \\
Anthracite only & $6.4 \pm 0.3$ & $6.3 \pm 0.5^{*}$ & $26.1 \pm 4.8$ & $5.6 \pm 0.6$ \\
$\quad$ (in series) & & & & \\
Anthracite + GAC & & & & \\
(overall) & $6.4 \pm 0.3$ & $1.4 \pm 0.1$ & $26.1 \pm 4.8$ & $3.5 \pm 0.2$
\end{tabular}

*Only eight effluent samples were analysed for the removal of DOC by anthracite because the removals in the samples analysed were extremely low.

${ }^{1}$ Mean \pm standard error 
Table 4. Effect of flow velocity on DOC and turbidity removals (based on 9-11 samples taken daily for 2 consecutive days for each velocity)

\begin{tabular}{|c|c|c|c|c|c|c|}
\hline \multirow{2}{*}{$\begin{array}{l}\text { Velocity } \\
(\mathrm{m} / \mathrm{h})\end{array}$} & Influent & Removal ef & ency of DOC & Influent & \multicolumn{2}{|c|}{$\begin{array}{c}\text { Removal efficiency of } \\
\text { turbidity }(\%)\end{array}$} \\
\hline & $(\mathrm{mg} / \mathrm{L})^{1}$ & $\mathrm{GAC}^{1}$ & $\begin{array}{c}\text { anthracite + } \\
\text { GAC }^{1}\end{array}$ & $(\mathrm{NTU})^{1}$ & $\mathrm{GAC}^{1}$ & $\begin{array}{l}\text { anthracite + } \\
\text { GAC }^{1}\end{array}$ \\
\hline 5 & $6.6 \pm 0.6$ & $82.6 \pm 2.1$ & $83.7 \pm 1.9$ & $55.2 \pm 11.2$ & $83.8 \pm 2.3$ & $87.1 \pm 1.6$ \\
\hline 10 & $5.0 \pm 0.1$ & $61.8 \pm 1.1$ & $76.0 \pm 2.4$ & $9.9 \pm 1.5$ & $50.7 \pm 7.0$ & $69.5 \pm 5.6$ \\
\hline 11.5 & $7.6 \pm 0.4$ & $68.9 \pm 2.3$ & $72.5 \pm 2.1$ & $10.9 \pm 1.1$ & $58.6 \pm 4.3$ & $65.9 \pm 3.5$ \\
\hline
\end{tabular}

\footnotetext{
${ }^{\mathrm{I}}$ Mean \pm standard error
} 
Table 5. Percentage* of cumulative removals of heavy metals by GAC after $120 \mathrm{~h}$ (666 BV) at pH 6.9-7.2 (Influent concentrations (mg/L): Zn 1.99, Cu 0.87, Cd 0.06, Ni 0.08, $\mathrm{Pb} 0.90$ )

\begin{tabular}{lcccccc}
\hline & Units & $\mathrm{Ni}$ & $\mathrm{Cd}$ & $\mathrm{Zn}$ & $\mathrm{Cu}$ & $\mathrm{Pb}$ \\
\hline Total metals added & $\mathrm{mg}$ & 15 & 12 & 388 & 168 & 174 \\
Metals removed by GAC, q total & $\mathrm{mg}$ & 3 & 2 & 147 & 143 & 151 \\
Metals removed by GAC* & $(\%)$ & 20 & 21 & 38 & 85 & 87
\end{tabular}

*Percentage of cumulative metal removal $=($ cumulative metal added - cumulative metal in effluent) / cumulative metal added 


\section{Figure Captions}

Fig. 1. Schematic diagrams of GAC filtration set-up used in the (a) field study and (b) laboratory study (diagrams not to scale).

Fig. 2. (a) DOC and (b) turbidity removals from stormwater by GAC, and anthracite + GAC columns at velocities of 5,10 , and $11.5 \mathrm{~m} / \mathrm{h}$ for days $1-2,3-4$, and $5-6$, respectively in the field (column height $1 \mathrm{~m}$ ).

Fig. 3. Removal efficiencies of single metals adsorption on GAC at $\mathrm{pH} 6.5$ in laboratory batch experiments (initial metal concentration $5 \mathrm{mg} / \mathrm{L}$, adsorbent doses 0.1-7.5 g/L, $24 \mathrm{~h}$ shaking).

Fig. 4. Removal efficiencies of mixed metals on GAC at $\mathrm{pH} 6.5$ in laboratory batch experiments (initial metal concentrations (mg/L): $\mathrm{Zn} \mathrm{10.0,} \mathrm{Cd} \mathrm{0.2,} \mathrm{Ni}$ 0.3, $\mathrm{Pb} 5.0$, and $\mathrm{Cu} 3.0$, adsorbent doses 0.5-10 g/L, $24 \mathrm{~h}$ shaking).

Fig. 5. Breakthrough plots of (a) $\mathrm{Ni}$, (b) $\mathrm{Cd}$, (c) $\mathrm{Zn}$, (d) $\mathrm{Cu}$ and (e) $\mathrm{Pb}$ in $\mathrm{GAC}$ column in the laboratory for mixed metals (column height $0.9 \mathrm{~m}$, filtration velocity $5 \mathrm{~m} / \mathrm{h}$, influent $\mathrm{pH}$ 6.97.2, initial metal concentrations (mg/L): $\mathrm{Zn} \mathrm{2.0,} \mathrm{Cd}$ 0.04, Ni 0.06, $\mathrm{Pb} 1.0$, and $\mathrm{Cu} 0.6$ ).

Fig. 6. Influent and effluent values of (a) DOC and (b) turbidity in GAC column in the laboratory using synthetic stormwater (column height $0.9 \mathrm{~m}$, filtration velocity $5 \mathrm{~m} / \mathrm{h}$, influent $\mathrm{pH}$ 6.9-7.2). 


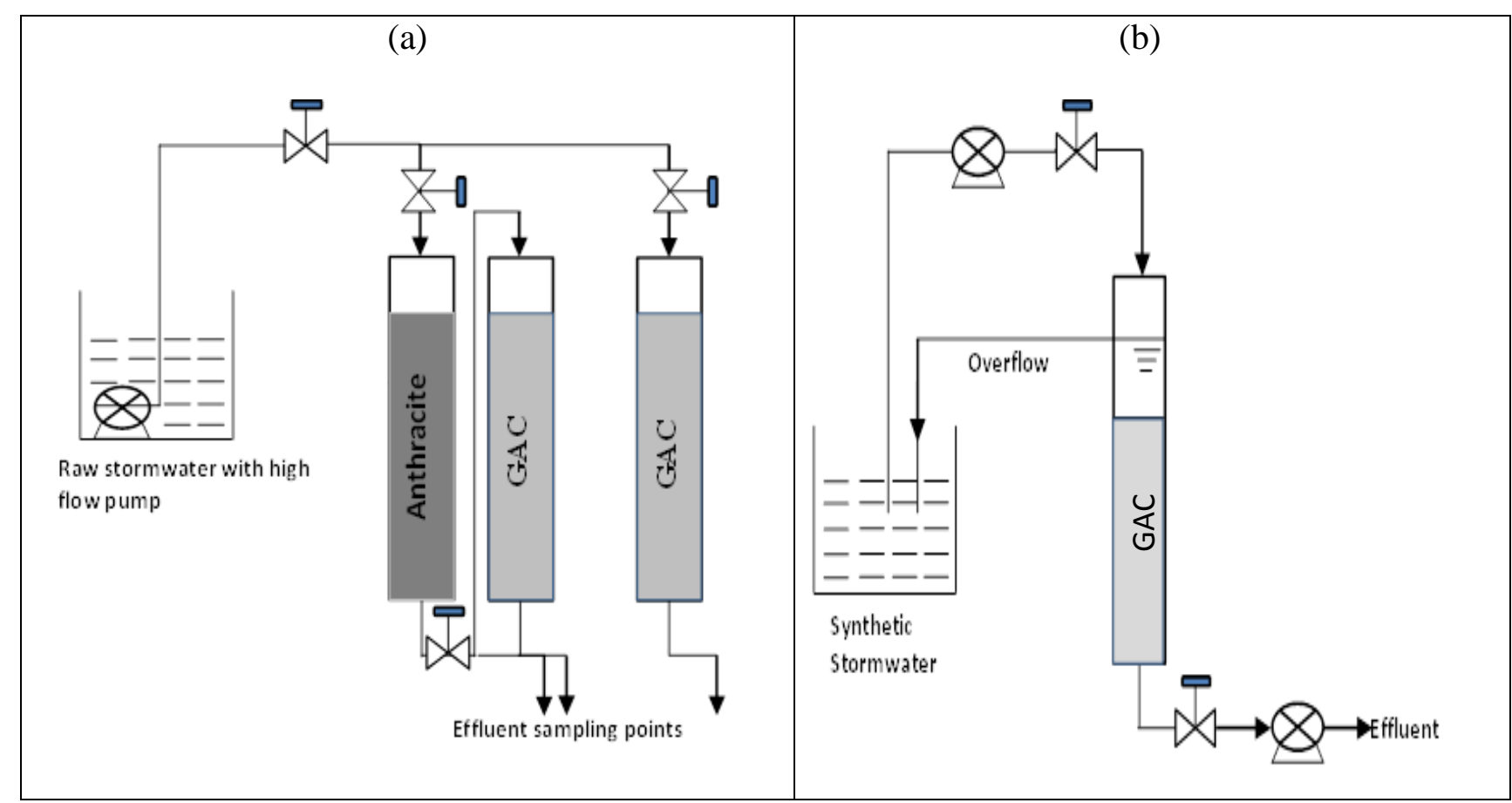

Fig.1. 


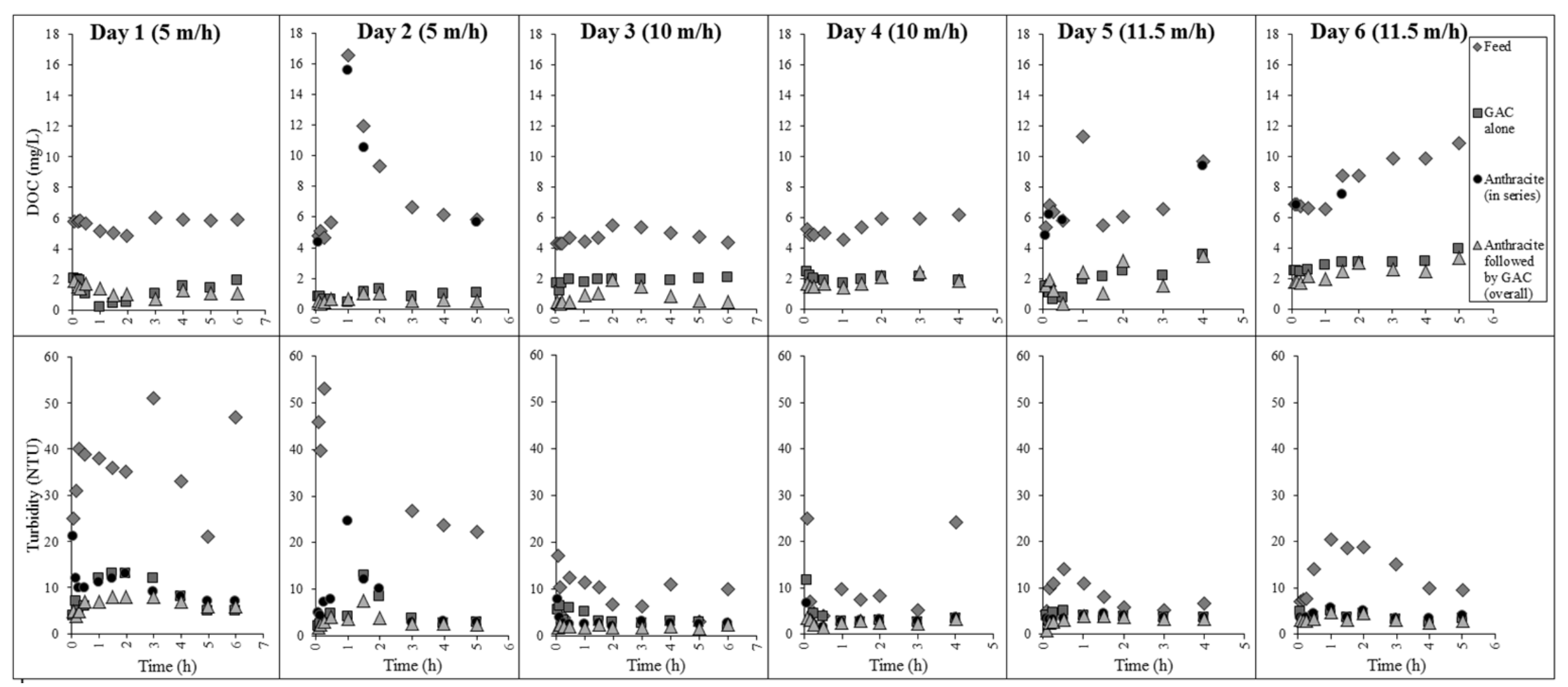

Fig.2. 


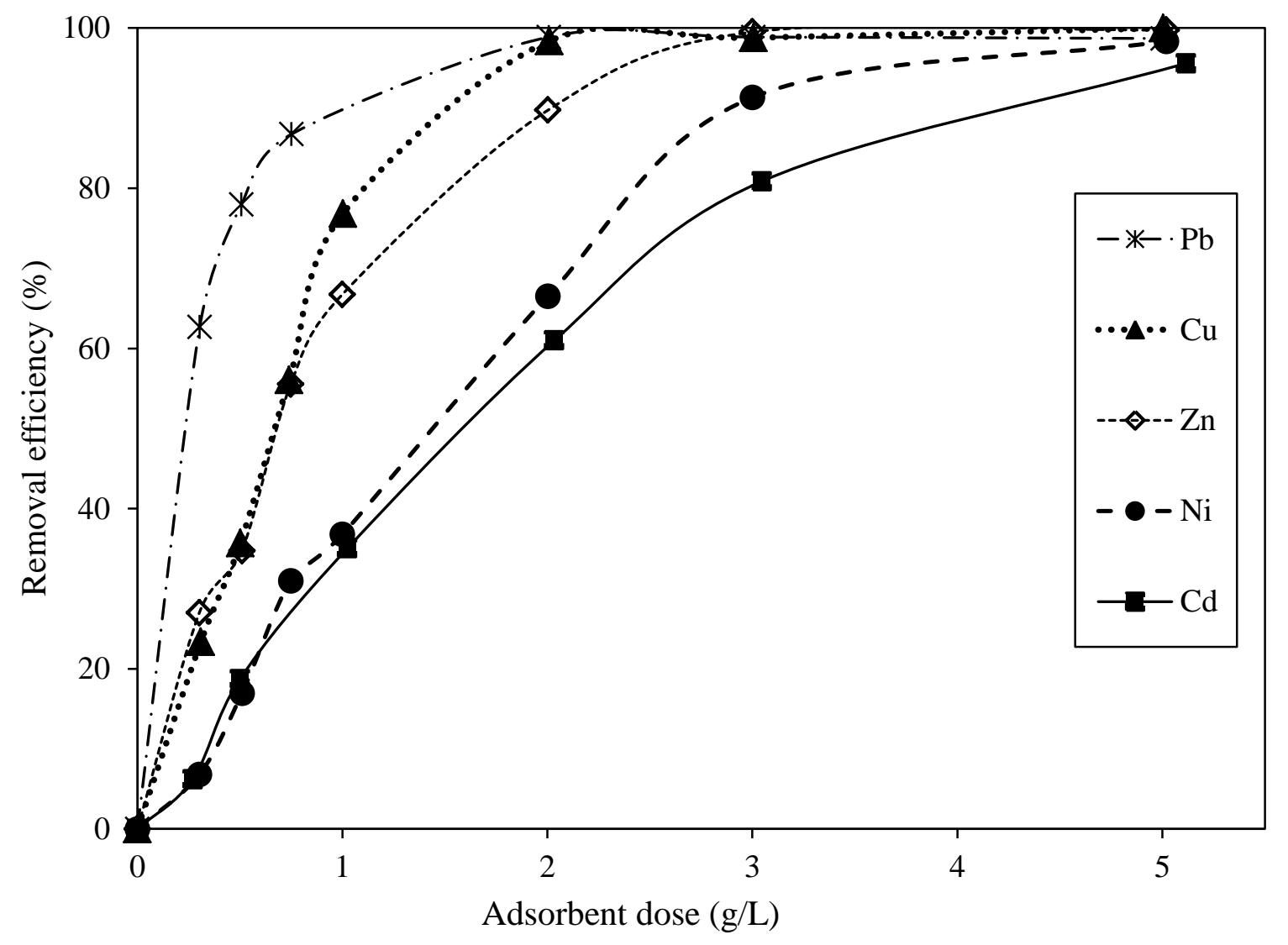

Fig. 3. 


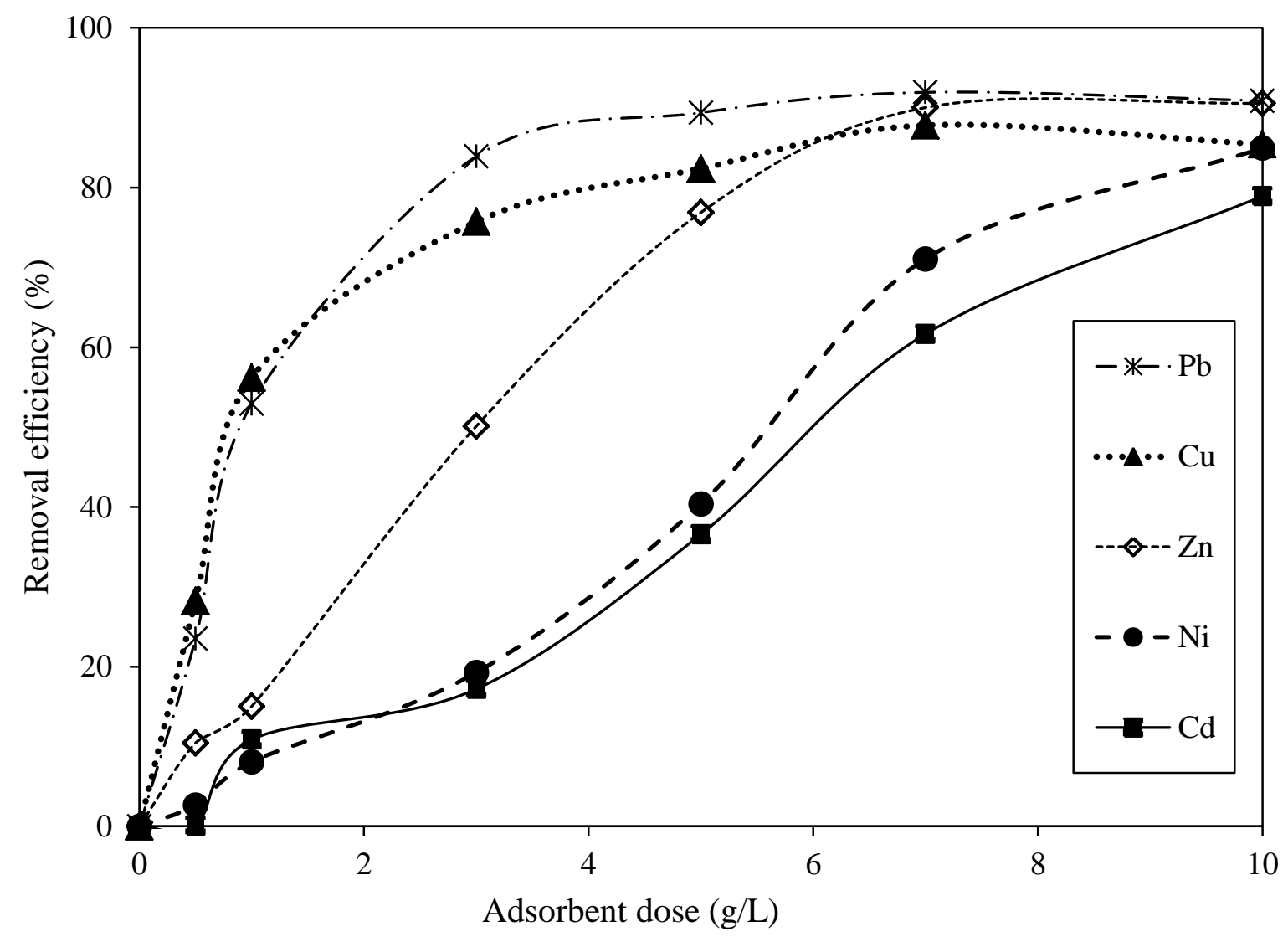

Fig. 4. 

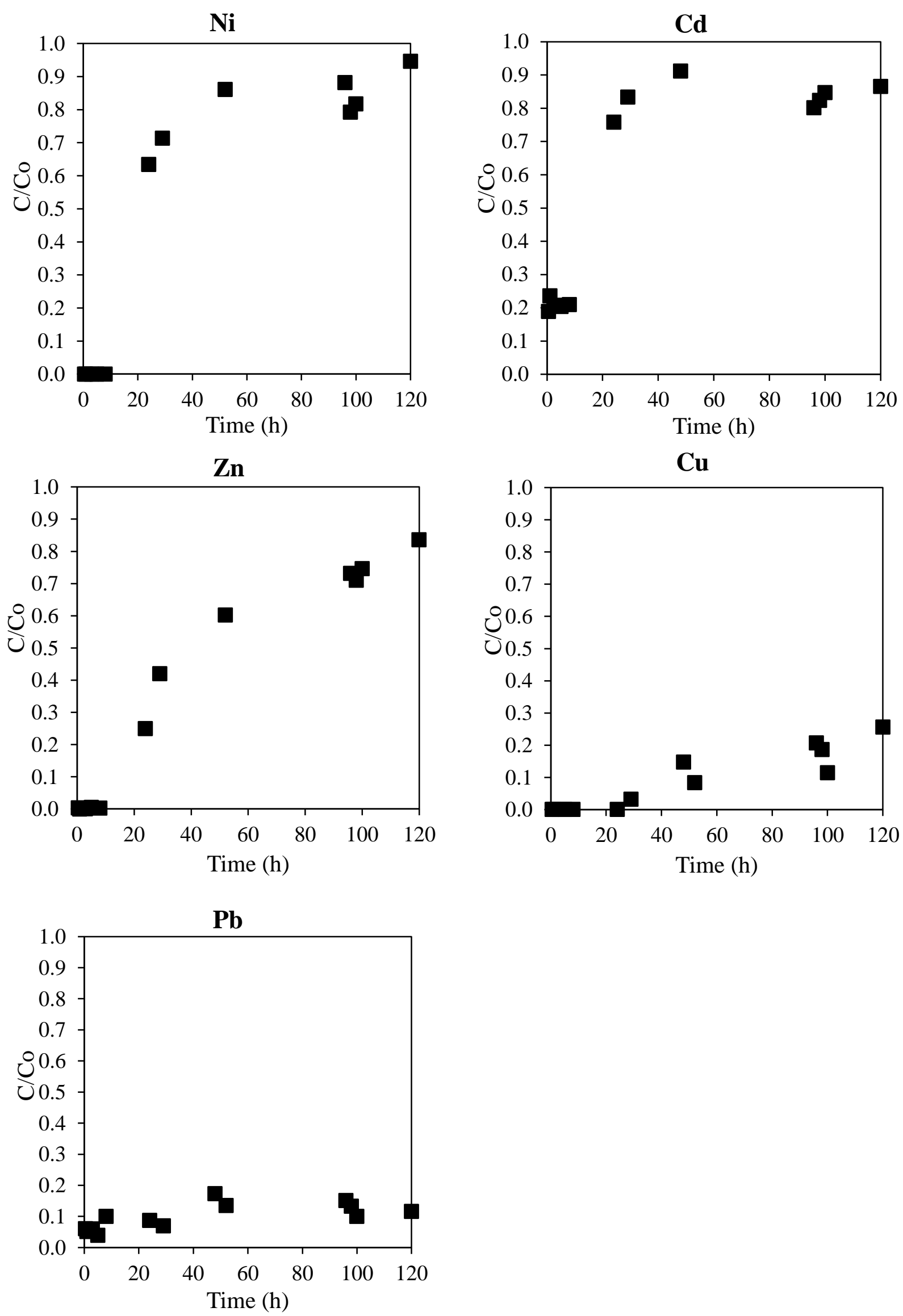

Fig. 5. 
(a)

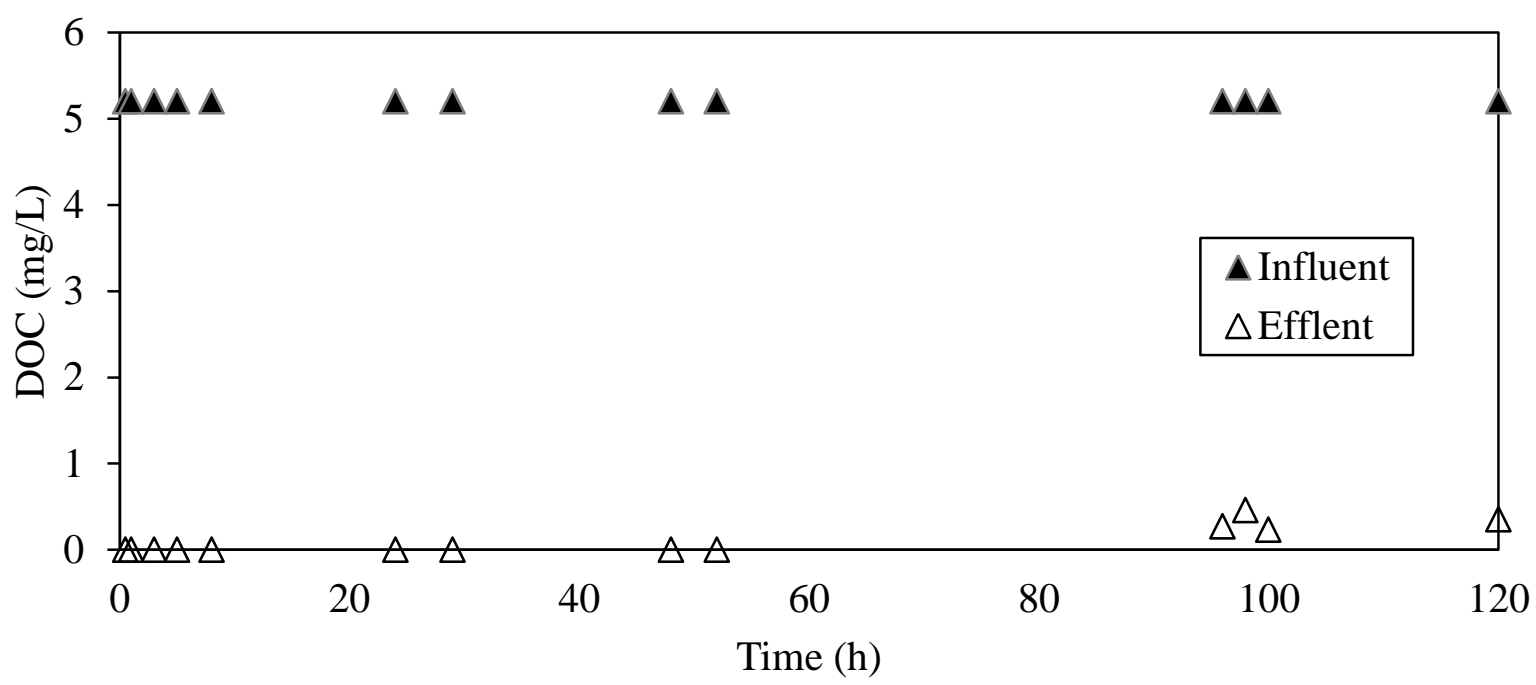

(b)

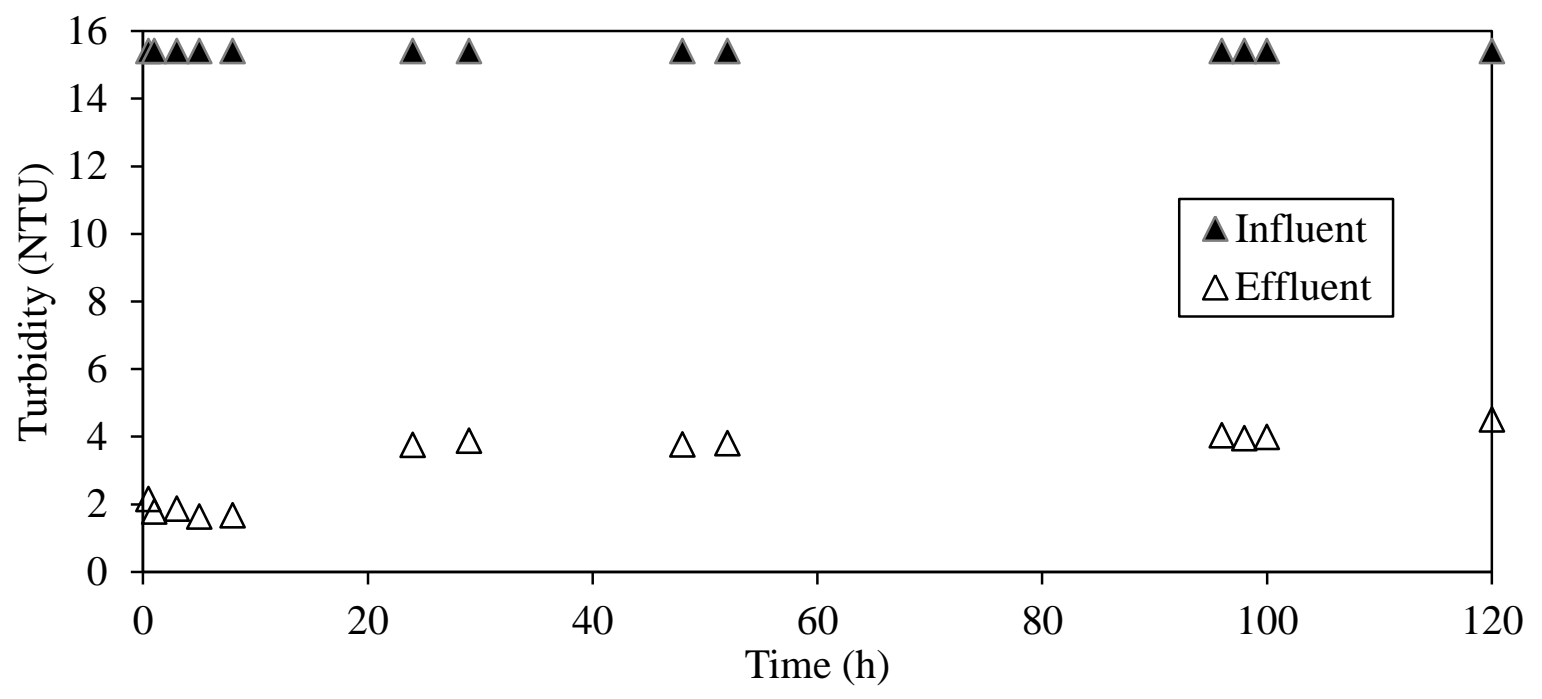

Fig. 6. 